\title{
AN AIRBORNE CAPABILITY FOR SOUTH AFRICA FROM A SPECIAL OPERATIONS FORCES PERSPECTIVE
}

\section{Evert Jordaan, Deputy Director Defence Policy Formulation, South African Defence Secretariat}

\begin{abstract}
Special Operations Forces (SOF) have received significant emphasis over the last decade, as armed forces require highly trained and rapid deployable forces to deal with asymmetric threats. The South African (SA) Army identified the need for an SOF capability in its long-term strategy, and airborne forces form an important component in its envisioned Contingency Brigade. This article examines the utility of contemporary airborne forces despite the decline in major parachute assaults. It also explains the importance of airborne forces for South Africa with reference to its defence policy and defence commitments. The article concludes that an SOF capability will enable the SA Army to operate better across the conflict spectrum, including robust multinational peace operations in Africa, which mostly involve insurgencies. The article also argues that South Africa needs a balanced airborne capability before it can establish an SOF capability. The intended conversion of airborne forces to SOF will require considerable changes in training and doctrine.
\end{abstract}

\section{Introduction}

Since the terror attacks on the US on 11 September 2001, the need for

Scientia Militaria, South African Journal of Military Studies, Vol 40, Nr 1, 2012, pp. 49- 70. doi: $10.5787 / 40-1-984$
Special Operations Forces (SOF) increased dramatically, even in countries such as Canada, which for long had a defence force largely oriented for peacekeeping missions. ${ }^{1}$ The current emphasis on SOF emerged as

\footnotetext{
* The views and arguments expressed in this article are those of the author and not the official views of the South African National Defence Force or the broader Department of Defence.
} 
countries required highly trained, rapidly deployable and adaptable forces to enhance their national security against asymmetric threats or to augment their expeditionary capabilities. The SA Army also identified the need for an SOF capability in its long-term strategy (the Future SA Army Strategy) ${ }^{2}$ in the form of an SOF brigade (Contingency Brigade) for crisis response operations in Africa within the context of multinational peace missions. Airborne forces form an important part of this envisioned capability, and the SA Army intends to convert its airborne forces into SOF.

Airborne and particularly air-landed ${ }^{\dagger}$ operations have been used extensively in the post-Cold War era, particularly by SOF. A well-known example is the deployment of the US $82^{\text {nd }}$ Airborne Division on the Saudi Arabia and Iraq border in 1990 in the event of an Iraqi attack during Operation Desert Shield as part of the liberation of Kuwait. The heavy lift capacity and strategic reach of modern transport aircraft enable large forces to be assembled on short notice to project forces strategically. Parachute assault operations have, however, become less prominent world-wide to project SOF strategically and tactically, due the high-risk nature of such operations and the advantages of using helicopters for trooping in theatre. Few large-scale parachute assault operations have therefore been conducted since the end of the Cold War.

The large-scale airborne operations of the Second World War left many (even current) military decision-makers with the perception that parachute assault operations enjoyed few successes and had been too wasteful in terms of lives. The question can therefore be asked: What is the relevance of an airborne (parachute) capability for South Africa from an SOF perspective, and what role should it fulfil? The aim of this article is to assess the relevance of an airborne and particularly a parachute capability for South Africa from an SOF perspective, by looking at contemporary requirements.

The article starts by defining the term "Special Operations Forces" and distinguishing these forces from normal units and special forces by explaining what SOF should be able to do. Secondly, the relevance of airborne forces in an SOF context will be discussed. Thirdly, South Africa's need for airborne forces and what

\footnotetext{
${ }^{\dagger}$ Air-landed operations involve movement by air with a designated destination for further ground deployment of units and personnel and/or further ground distribution of supplies. Source: US Department of Defence, JP 1-02, DOD Dictionary of Military and Associated Terms, 8 November 2010, as amended by 31 December 2010.
} 
they should be trained for, will be discussed. The SA Army's future concept for an SOF capability with its envisioned Contingency Brigade will also receive attention. Lastly, some challenges for South Africa's airborne capability will be discussed in terms of building an SOF capability.

\section{Understanding Special Operations Forces}

The term SOF is often used very loosely to refer to airborne troops, ${ }^{\dagger}$ special operations forces and special forces. There can be large differences between such forces in different countries and therefore the term SOF needs to be clarified. Special operations forces can generally be defined as

... specially selected, organized, trained, and equipped military and paramilitary forces that conduct high-risk, high-value special operations to achieve military, political, economic, or informational objectives by generally unconventional means in hostile, denied, or politically sensitive areas, in peace, conflict or war. ${ }^{3}$

Colin Gray explained that SOF "... undertake missions that regular forces either cannot perform or cannot perform at acceptable cost." ${ }^{, 4}$ Examples of SOF missions include raids behind enemy lines, sabotage, reconnaissance and unconventional warfare. Some SOF have a wide range of tasks. The core tasks of US Army SOF for example are unconventional warfare, foreign internal defence, direct action, special reconnaissance, counter-terrorism, psychological operations, civil affairs operations, and counter-proliferation of weapons of mass destruction. ${ }^{5}$

In most countries with SOF, these forces form an additional component of joint operations with their own command structure that can employ them independently from different services. ${ }^{6}$ Special operations forces form a critical component in modern armed forces and are not considered mere force multipliers or add-ons. They are considered the most flexible forces that will remain in high demand in future warfare as they can deploy on short notice and best operate across the conflict spectrum. They also have the ability to achieve objectives out of proportion to their numbers, which in certain situations make them less expensive than large, inflexible forces.

\footnotetext{
* Airborne troops can be defined as soldiers especially trained to effect, following transport by air, an assault debarkation, by either parachuting or touchdown. Source: US Department of Defence, JP 1-02, DOD Dictionary of Military and Associated Terms, 08 November 2010, as amended through 31 December 2010.
} 
Special operations forces do not exclude special forces (SF), but not all SOF are special forces. One way to try to distinguish between SF and other SOF is to look at selection criteria, and the criteria for SF are usually significantly higher than other SOF. SF missions also tend to be more clandestine and covert than those of SOF. For example, SF are often used to train irregular forces.

A three-tier system can be used to more or less distinguish between different levels of SOF. ${ }^{\S}$ Tier 1 SOF are typically selected for high-risk tasks such as counterterrorism hostage rescue operations and include organisations such as special forces. ${ }^{7}$ Tier 2 SOF missions may include high-value tasks such as strategic reconnaissance. These SOF are usually selected before they are properly trained, because of the difficult skill sets and attributes that are required. Tier 3 SOF include selected forces such as the US Rangers whose missions include direct actions such as raids, direct assaults and sabotage in hostile or denied areas. Such SOF usually receive training as part of their selection. ${ }^{8}$ This article focuses mainly on Tier 3 SOF (when referring to SOF).

Airborne forces are most often not considered SOF. The question may be asked: Which airborne forces can then be classified as SOF? This may be a difficult question to answer. Many airborne units in the world have tough selection and training standards that could classify them as Tier 3 and even Tier 2 SOF levels. ${ }^{9}$ The selection standards and specialised training for airborne and/or parachutequalified troops are, however, not the same across defence forces, although airborne units across the world generally share elite attitudinal, cultural and philosophical traits such as tenacity of purpose, no mission too daunting and disdain for those outside the group. There are no clear answers on this, as the physical and psychological demands of various airborne courses differ.

A different way to determine what SOF entails is to determine what they should be able to do from a capability point of view, which will provide a qualitative benchmark for SOF. According to Horn, SOF should be on high-readiness state and be able to engage in operations on very short notice without having secure airfields, beaches, ports, or other points of entry. ${ }^{10}$ A country should be able to project its SOF strategically, even into an opponent's depth. The ability to deploy SOF via air, sea

\footnotetext{
$\S$ The three-tier system also refers to the different and decreasing success rates on courses (in percentages) from Tier 3 to Tier 1-type SOF, which can be misleading if used arbitrarily to distinguish between different levels or types of SOF.
} 
and land is therefore a necessity. Although SOF should have sufficient firepower, their stealth, ability to infiltrate and speed of movement over difficult terrain are more important. In addition to raids, direct assaults and sabotage, SOF should be able to conduct air assaults, ambushes, attacks by infiltration, strikes at an opponent's key points, and deep penetration of an opponent's territory. Special operations forces should be used more extensively for offensive tasks than special forces. The latter's role is more clinical and strategic and their capability should not be misused for tasks that Tier 3 SOF are capable of. Special operations forces can support special forces by providing safe perimeters to operate, especially in hostile areas. Another important role of SOF is to conduct long-range reconnaissance. Electronic surveillance cannot replace the detailed tactical information that SOF reconnaissance teams on the ground can provide. Special operations forces should also be experts at counter-insurgency, although such operations are by no means limited to SOF.

If a country maintains a credible SOF capability, it can serve as a deterrent against potential aggressors for national defence, or deter spoilers and rebels in peace missions. The strategic reach and rapid deployment of SOF is among others dependent on an airborne capability, which will be discussed later. Since this article focuses on parachute forces, contemporary examples of parachute assaults by SOF will be provided.

\section{Parachute assault operations in the post-Cold War era}

In the post-Cold War era, only the US conducted parachute assault operations on significant scale. Following the terror attacks on the US on 11 September 2001, the US demonstrated its ability to rapidly project forces to remote theatres by means of airborne operations. On 19 October 2001, 199 US Rangers did a parachute assault (raid) on an abandoned airfield southeast of Kandahar in Afghanistan and secured it with the support of AC-130 Spector gunships. ${ }^{11}$ The Rangers then supported other SOF elements with further raids in the area including a raid on the residence on Mullah Mohammed Omar, the founder and leader of the Taliban. ${ }^{12}$ Although Omar was not captured during this operation, the US demonstrated its ability to operate in the strategic depth of the Taliban.

On 26 March 2003, during the US invasion of Iraq, the US $173^{\text {rd }}$ Airborne Brigade, based in Italy, did a combat drop with 959 troopers on Bashur Airfield in northern $\operatorname{Iraq}^{13}$ as a deception plan for the war's northern front and to reinforce special forces teams working with the Kurdish Peshmerga militia. ${ }^{14}$ The drop zone was secured by SF and Central Intelligence Agency (CIA) operatives. This airborne 
operation combined with air attacks and Peshmerga attacks resulted in the Iraqi withdrawal from certain areas in the north. The $173^{\text {rd }}$ Airborne Brigade then cooperated with special forces and Kurdish forces in northern Iraq.

On 27 March 2003, several companies of US Rangers conducted a parachute assault on the H-1 airfield near Qadisiyah as part of a larger operation to gain control over the western Iraqi desert. ${ }^{15}$ This operation enabled the US to gain control of the Haditha Dam. Thereafter the Rangers were reinforced with an armoured company for further operations in the desert.

The above-mentioned US parachute assaults in Afghanistan and Iraq met little resistance and were well supported by other elements such as SOF and air power. This reduced the risks of these airborne operations.

\section{The relevance of an airborne capability}

When looking at the relevance of airborne forces, it is important to note that they cannot win wars on their own. Since their early development, airborne forces are only enablers for success in combat operations within a theatre, although independently they may be able to destroy and occupy objectives of strategic significance or succeed in short, low-intensity operations such as extracting citizens from a country caught up in a sudden civil war. One of the closest examples of the near independent success of airborne operations in war was the German parachute assault on Crete, which, without air support and later reinforcements via air, would have ended in total disaster. ${ }^{16}$ The role of airborne forces in combat operations can therefore often not be divorced from the supporting role of air and maritime power, as well as heavier and more mobile landward forces.

The modern concept of airborne operations has moved away from the massed divisional or corps drops of the Second World War and more towards smaller operations of between battalion- and brigade-strength. ${ }^{17}$ The decline in interstate conflict since the end of the Cold War had a direct impact on the decline in parachute assaults and the downscaling of airborne forces world-wide. According to Horn, most North Atlantic Treaty Organisation (NATO) countries do not consider airborne operations as the preferred method of operations due to modern threats by surface-to-air missile (SAM) technology, problems with logistical support and the current easier methods of moving troops into the battle space. ${ }^{18}$

The variety and prominence of anti-aircraft threats have increased the risk of employing airborne forces. On the modern high-technology battlefield, even with air 
superiority, the resupply of airborne forces is difficult considering that there remains a three-dimensional 360-degree threat, particularly from ground forces. ${ }^{19}$

Looking at the future battlefield from a British perspective and with reference to the post-Cold War era, Harclerode argues that the concept of airborne operations against sophisticated opponents should change significantly. ${ }^{20}$ Considering modern air defence systems, he argues that in future, paratroopers have to be dropped below radar at low altitude (approximately 300 feet) and be delivered onto multiple drop zones as near as possible to their objective/s, which today is possible with modern low-altitude parachutes.

In sub-Saharan Africa, long- and medium-range surface-to-air missiles (SAMs) do not present a major threat as there are very few in use, while shoulderlaunched SAMs are an unpredictable threat in Africa and more widely available. For example, in November 2002, two Soviet-made Strela-2 shoulder-launched SAMs were fired at an Israeli-chartered aircraft of Arkia airline, shortly after take-off from Mombasa in Kenya, which narrowly missed it. ${ }^{21}$ Rocket-propelled grenades (RPGs) and particularly those modified with time delay for air-burst, pose a major threat to helicopters and transport aircraft at low altitudes. ${ }^{22}$ Such modified RPG-7s shot down the US Black Hawk helicopters in Mogadishu (Somalia) in October 1993. Anti-aircraft guns are found in great numbers in most African countries and also present a major threat to airborne operations. Anti-aircraft weapons are often bolted onto $4 \times 4$ vehicles (commonly known as "technicals") or trucks and are used against personnel, vehicles and low-flying aircraft. These technicals are often massed for attacks against their opponents or even peacekeepers.

Airborne operations are, however, not outmoded. According to Heitman, the use of mass parachute assaults may be largely outdated, but airborne operations are part of modern warfare. ${ }^{23}$ An airborne capability provides the ability to insert forces in denied, hostile, austere or remote areas. ${ }^{24}$ They offer quick, mass delivery of forces, as well as more clinical delivery of SOF elements. Roles for airborne forces that will remain important include holding airheads or ports of entry, as well as airborne raids to engage insurgents in remote areas. Airborne forces can ensure that an objective is saturated with the required combat power to secure an area for linkup with other forces.

The threat of a pending airborne assault can also be used to coerce a regime to submit to certain political terms. When Haiti fell into chaos in the 1990s, after the Haitian military grabbed power from Bertrand Aristide, the US threatened the military regime of General Raoul Cedras with an airborne invasion if they did not 
return the country to democratic rule. In September 1994, the US mobilised its airborne forces to conduct an intervention operation in Haiti. Retired General Colin Powell who formed part of the US political team, told General Cedras and his other generals “... if you don't abdicate your power ... we're coming in here and we're going to kill you all". ${ }^{25}$ Cedras gave in and the US reinstated president Bertrand Aristide and helped to prepare the country for new elections. In March 1995, the US handed over the mission to a United Nations contingent. An airborne capability could therefore be quite relevant as a deterrent to maintain peace and security.

The training value of airborne forces to produce aggressive, motivated and combat-capable troops should not be underestimated. ${ }^{26}$ An airborne training capability also supports special forces and para-military forces. Having troops that are willing to enter high-risk situations provides valuable psychological advantages.

The question now arises: What should airborne forces look like? According to Horn, the smallest element for an effective airborne capability is a battalion consisting of three rifle companies, a support company (which provides additional firepower and specialised combat support elements), as well as combat service support elements. ${ }^{27}$ The three companies provide the ability to engage multiple targets and maintain a mobile reserve. An airborne unit provides a cohesive setup for shared standard operating procedures (SOPs), tactics, techniques and procedures (TTPs) and an integral homogenous command and control element. It is also the centre for maintaining, administrating and mass training an airborne capability. The airborne battalion as a whole therefore forms a critical element and building block for an airborne capability.

On its own, however, an airborne battalion cannot fully function and it is not a balanced capability. Ideally, an airborne capability should form part of a brigade structure (usually consisting of three airborne battalions) with all the supporting arms and units, as well as command and control, signals, logistics (including air supply), medical and other specialised force components. Currently, the SANDF only has a parachute regiment headquarters for the parachute capability, which is inadequate to coordinate the parachute-trained elements of the artillery, air defence and engineers.

\section{Why South Africa needs an airborne capability}

Although the modern-day relevance of airborne forces was reiterated earlier, the question may still be asked: Why does South Africa need an airborne capability? 
This can be answered by looking at South Africa's defence policy, international commitments and the type of operations it should be prepared for.

According to the 1998 Defence Review, a parachute and SF capability (together with mechanised forces) is required to deal with shorter-term contingencies for landward defence. The approved force design of the SANDF makes provision for these capabilities. The Defence Review furthermore states that the SANDF should have one regular and one reserve parachute battalion (1 Parachute Battalion and 2 Parachute Battalion respectively). ${ }^{28}$

The need for an airborne capability in South Africa should be understood within the broader context of multinational peace and stability operations in Africa. From a foreign policy perspective, it is in South Africa's interest to promote peace and stability in Africa. The 1999 White Paper on South African Participation in International Peace Missions states that the "... peaceful resolution of seemingly intractable conflicts compels us to participate in peace missions to alleviate the plight of other peoples who are struggling to resolve similar conflicts". ${ }^{29}$ South Africa's emphasis on peace and stability was clearly displayed when the SANDF became increasingly involved in peace missions in Africa since 1999 to the extent that, until recently, it had the equivalent of approximately three battalions deployed in African peace missions.

As a member of the African Union (AU) and its Africa Standby Force (ASF), and particularly the Southern Africa Development Community (SADC) Standby Force, South Africa has to ensure that the South African National Defence Force (SANDF) remains prepared for a wide variety of contingencies as part of these security structures. According to the Protocol Relating to the Establishment of the Peace and Security Council of the African Union, the AU has the mandate to authorise a wide spectrum of operations ranging from intervention operations, peace support operations, to humanitarian operations. ${ }^{30}$ In addition, the SADC Defence Pact presupposes that a collective response to military aggression against a member state is only possible if signatories "... by means of continuous co-operation and assistance, maintain and develop their individual and collective self-defence capacity to maintain peace, stability and security". ${ }^{31}$ In addition, the AU or SADC may at any stage, through its deliberations and appreciations, identify a requirement for one or more military capabilities within or outside the scope of existing pledges. ${ }^{32}$ According to Schöultz, "One of the founding provisions [of the AU Standby Force] was that there had to be a force capable of acting anywhere on the continent, should the need arise." 33 South Africa therefore has to maintain the ability 
to defend itself, to conduct peace enforcement, peace support and humanitarian operations - all within the context of multinational operations.

South Africa has pledged (among others) a parachute battalion for the SADC Standby Force, which should be kept combat-ready in fulfilment of this commitment. ${ }^{34}$ This unit should be able to deploy within 14 days for intervention operations, and within 30 days for complex multidimensional peacekeeping missions as well as preventative deployments. ${ }^{35}$ The designated unit for this commitment is 1 Parachute Battalion, which is the only regular parachute unit in the SANDF. This unit also serves as a reserve of the Chief of the SANDF for rapid response operations. Therefore, 1 Parachute Battalion fulfils a strategic purpose for both the SADC and South Africa, and must be kept on a high level of readiness. No unit can, however, be kept on high readiness indefinitely. The alternative unit as Chief of the SANDF's reserve is usually 6 South African Infantry (SAI) Battalion, which is trained as an air-landed (helicopter-landed) battalion. Since this unit is not a parachute unit, it cannot substitute 1 Parachute Battalion as the pledged parachute unit for the SADC Standby Force.

Since 2009, the SADC started to expect that forces pledged for the SADC Standby Force could not be deployed forces at the same time and should at all times be ready for inspection in the particular country. According to Mandrup, SADC countries experience some challenges with the readiness, inspection and rotation of pledged forces. ${ }^{36}$ The SANDF should therefore have a rotation system for 1 Parachute Battalion to ensure readiness for and compliance with the pledges for the SADC Standby Force. One way of doing this is to renegotiate the pledged "parachute battalion" to an "airborne battalion" (parachute or air-landed) to allow 6 SAI to rotate with 1 Parachute Battalion, which will allow the latter unit and its sub-units to deploy more regularly in peace missions. Ideally, a more elaborate airborne capability should be developed to maintain South Africa's commitments to the SADC Standby Force, as well as to ensure a rapid deployable capability in the SANDF. With SOF training, such a capability will be very flexible and able to operate across the spectrum of conflict.

\section{The SA Army's SOF concept: The Contingency Brigade}

As mentioned earlier, the SA Army, like many other armed forces, identified the need for an SOF capability for crisis response operations in the form of an SOF brigade. This future SA Army concept for SOF will now receive attention. 
The idea with the envisioned Contingency Brigade is that of a balanced rapid reaction force that can be deployed, supported and sustained by air within 48 hours. ${ }^{37}$ This brigade, together with its support units and elements, such as engineers and light artillery, will consist of three strengthened battalions (battalion groups), one parachute, one air-landed and one sea-landed. Each of these battalion groups will have a similar battalion group consisting of reserves to shadow it.

As a modular rapid reaction force, which can be tailored for particular situations, the envisioned Contingency Brigade will be an operational reserve that can be employed by the Chief of the SANDF at short notice. ${ }^{38}$ It will be mainly responsible for early-entry and crisis response operations. It must also be able to conduct deep operations in support of other forces. ${ }^{39}$ It should be able to employ network-enabled systems to have joint command and control and intelligence, surveillance and reconnaissance systems, as well as joint firepower.

Joint firepower is considered a critical support requirement for the Contingency Brigade, particularly for its sea-landed and parachute elements, which usually have limited tactical mobility when deployed, up until link-up forces arrive. ${ }^{40}$ This may include naval gunfire support, artillery and air support. While the helicopter-borne air-landed troops should have more tactical and operational mobility, they are also vulnerable as light forces and will be dependent on joint firepower. Attack helicopters are considered an important support element to reduce the vulnerability of these light forces, particularly for close air support, reconnaissance and surveillance.

As special operations forces, soldiers of the Contingency Brigade will have to be trained to above-average standards. ${ }^{41}$ Some of the training may for example include advanced medical training, advanced navigation skills, advanced reconnaissance skills, small boat operations, ship-to-shore operations, hand-to-hand combat, forward air controlling, urban fighting, mountaineering skills, as well as survival and demolition. To compensate for the weakness of its light forces, all elements of the Contingency Brigade will have to be trained in aspects such as night fighting and the Contingency Brigade must be able to exploit the element of surprise with rapid force projection.

The SA Army envisions that an SOF brigade headquarters will command 1 Parachute Battalion, a sea-landed and an air-landed battalion, other units and elements that comprise the Contingency Brigade. Other armed forces already restructured their SOF elements under such headquarters. For example, Britain closed down its airborne brigade headquarters in the late 1990s when the British 
Ministry of Defence consolidated all rapid reaction forces in the 16 Air Assault Brigade. At the time, the British airborne brigade included three parachute battalions and supporting arms. ${ }^{42}$

Grouping parachute battalions under SOF commands is therefore not something new, but the envisioned SA Army Contingency Brigade's staff will have to be trained formally to plan, execute and control special operations, parachute operations, as well as air and sea-landed operations. Such courses should be tailored according to future needs and be presented jointly with other services. The courses should be compulsory for future leaders working in the envisioned Contingency Brigade and should also be presented to other relevant service arms personnel earmarked to work with and support this brigade.

\section{South African paratrooper training and the requirements for Special Operations Forces training}

At the beginning of the article, qualitative aspects were covered to determine what constitutes SOF. A subsequent question that may arise is whether South African paratroopers ${ }^{* *}$ are of SOF quality. This is an important question for future force preparation, especially since there are different opinions about this among senior SA Army officers. One way to answer this question is to determine what South African paratroopers are trained for. For this, the composition of 1 Parachute Battalion should be taken into consideration, as it consists among others of three rifle companies, a support company (which comprises a mortar platoon, a machine gun platoon, an anti-tank platoon and an assault pioneer platoon), as well as a reconnaissance platoon.

After the successful completion of parachute training, South African paratroopers generally receive basic training in parachute assaults, helicopter assaults, air-landed operations and, recently, also training for fighting in built-up areas (FIBUA). ${ }^{43}$ The latter course forms part of an initiative to expand the specialisation training of paratroopers. Many paratroopers were trained in hot

\footnotetext{
** "Paratroopers" here refers to soldiers who are not only trained in parachuting, but also in conducting parachute assaults, air-landed and other airborne operations, as part of an airborne unit.
} 
extraction operations, but this has been downscaled in the parachute companies over the last few years and resides more with the pathfinder ${ }^{\dagger \dagger}$ platoon.

The reconnaissance platoon of 1 Parachute Battalion is trained to provide a battalion or company commander with a tactical reconnaissance capability within range of support weapons. This training is provided by the SA Army's Infantry School as part of a common reconnaissance platoon course for normal infantry units. Members attending this course are trained in basic survival, foreign weapons, medical support, urban and rural operations, as well as rope work. ${ }^{44}$

The average South African paratrooper (including members of the reconnaissance platoon) is not trained to do sabotage, counter-insurgency, infiltration or long-range tactical reconnaissance ${ }^{45}$ - tasks which Tier 3 SOF should be able to do. South African paratroopers can therefore not be classified as SOF, due to their limited specialised training.

The South African pathfinder platoon (which is a brigade-level asset) will, however, definitely fall within the ambit of SOF due to their more specialised training. Pathfinder training is very demanding and only about $40 \%$ of candidates (who are already qualified paratroopers) make this selection and attend the 42-week course. Pathfinder training includes (among others) escape and evasion, demolitions, advanced survival, medical support, reconnaissance, advanced urban operations, rope work, drop zone safety, as well as high-altitude-low-opening (HALO) and high-altitude-high-opening (HAHO) operations. ${ }^{46}$ Pathfinders are also trained to infiltrate on foot and by means of boats and vehicles.

While most South African paratroopers may not technically be classified as SOF soldiers considering their limited specialised training, South Africa's parachute community has a small SOF capability in the pathfinders. South Africa's special forces are also of SOF standard and will also be able to provide expertise to help develop a fully-fledged SOF capability in South Africa, among others from the airborne community and by means of training in more relevant specialised disciplines. Without the latter, an SOF brigade cannot be built.

Besides training, the role and employment of South African paratroopers should also be understood to determine the way forward in establishing an SOF

${ }^{\dagger}$ Pathfinders can be defined as paratroopers who are trained to parachute or air-land at an objective to establish and operate navigational aids for the purpose of guiding aircraft to drop and landing zones. 
capability. The current utilisation and doctrine of paratroopers have been significantly influenced by the roles they were employed in during the apartheid era against PLAN (People's Liberation Army of Namibia) liberation fighters in both Angola and Namibia, during the so-called Bush War of the 1970s and 1980s. During this war, paratroopers were employed mainly in three roles. ${ }^{47}$ Firstly and most commonly, they were employed as a reaction force (based on the "Fire Force" technique learned from the Rhodesians) to reinforce firefights against insurgents or to follow-up fresh insurgent tracks. Secondly, paratroopers were deployed in support of ground forces, which usually entailed acting as "stopper group" or "cut-off" group behind the insurgents' bases or concentrations (in order to seal off their escape routes) while under attack by ground forces. Occasionally, paratroopers were also used to conduct sweeps and offensive tasks such as assaults. The third role of paratroopers was that of independent airborne operations of which the parachute assault on Cassinga in 1978 is probably the best-known example. After this risky parachute assault, the South African Defence Force (SADF) stopped employing paratroopers strategically and independently - a trend which was later continued in the South African National Defence Force (SANDF), as was displayed with the penny-packet ${ }^{*}$ deployment of paratroopers during the 1998 intervention in Lesotho. The SADF and SANDF's tactical approach towards employing paratroopers relegated their role to being the "airborne arm" of ground forces. ${ }^{48}$

With the prominence of insurgency in Africa and the need for more robust multinational peace operations on the continent, 1 Parachute Battalion together with the envisioned air-landed and sea-landed battalions should become the SANDF's specialised units and centre of excellence in counter-insurgency, especially since this kind of training was stopped in the late 1990s. ${ }^{49}$ All army units and particularly infantry units should be trained to do counter-insurgency. Counter-insurgency involves among others patrolling, follow-up operations, direct actions, collecting information, helping local communities where possible, and pre-emptive operations.

The most successful SOF from South Africa's experience in counterinsurgency, were able to operate outside their in-theatre base areas (in the field) semi-independently for between six and eight weeks (without being relieved), but with in-field re-supply. They were also able to operate independently without any logistical support for at least seven days. While in field, they were able to group and regroup for operations against belligerents, and to continue with reconnaissance and

\# During the Second World WAR, British commanders used the term "penny packets" to describe small units and the improper dividing up and parceling out of airpower to ground forces. 
patrols afterward. ${ }^{50}$ The concept of linking up with SOF/airborne forces within 48 hours particularly after insertion, should only apply to high-intensity and conventional/warfighting-type operations. In other operations, such as counterinsurgency or low-intensity peace enforcement, SOF should be able to operate much more independently.

The conversion of South African airborne forces to SOF may, however, be difficult particularly since South African airborne forces have generally not been trained or employed to operate semi-independently to perform the specialised tasks of SOF. South African paratroopers rarely did parachute or helicopter insertion for lengthy patrols against insurgents during the Bush War. Although long marches have always been part of South African paratrooper training, long-range reconnaissance and semi-independent operations are, however, not characteristic of South African airborne doctrine. The conversion of airborne forces to SOF will be a long-term process and will require major changes in airborne and force employment doctrine.

\section{Realities and future considerations for South Africa's airborne capability}

The current nature and status of South Africa's airborne capability should be understood against the background of major defence spending cuts and subsequent loss of military capabilities in the new democratic dispensation. After the Bush War in 1990, 44 Parachute Brigade developed the capability to drop a parachute battalion group consisting of 600 troops with engineers, maintenance support, armoured cars, light artillery, logistic and command vehicles in one wave with 18 aircraft (12 x C130s/C-160s and 6 x Dakota C-47s). ${ }^{51}$ In 1991, this capability formed part of the Rapid Deployment Force for rapid response operations. As South Africa moved towards democracy, this capability could not be maintained due to a rapid decrease in the defence budget and changing defence priorities. Subsequently, 1 Parachute Battalion lost its strength as a battalion group when the artillery, air defence, engineers and other attached elements were returned to their respective corps. The erosion of South Africa's airborne capability as a result of continued defence budget cuts, ended the concept of independent strategic airborne operations. ${ }^{52}$ The potential for the independent and strategic use of airborne forces declined and a more tactical way of employing airborne forces became the norm.

The size of South Africa's airborne capability that can be employed at a given moment is largely determined by the South African Air Force's (SAAF) ability to provide sufficient numbers of fixed-wing transport aircraft (particularly the C-130s) for parachute assaults or air-landed operations, and helicopters (such as the 
Oryx) for rapid tactical deployment and extraction. The SAAF should have the required capacity to carry airborne forces and their equipment, as well as to support them with air superiority (if possible, though not a precondition), close air support, air supply, communication and command and control. To drop a whole parachute battalion in one wave with its vehicles, technical personnel and a surgical post will require at least twelve $\mathrm{C}-130 \mathrm{~s}$, while dropping a battalion group will currently require nineteen $\mathrm{C}-130$ transport aircraft. ${ }^{53}$ To drop a conventional battalion of paratroopers without their equipment will require ten $\mathrm{C}-130$ s. According to airborne doctrine, at least one third of a parachute assault force should be dropped in the first wave, which is usually at least a company for a battalion and a strengthened company for a battalion-group drop, of which the latter will require between four and ideally five C-130s. ${ }^{54}$

The SAAF discarded its C-160s, which left it with a small fleet of C-130s. Currently, the SAAF has nine C-130s of which only seven are currently in circulation and it is almost impossible to have all seven serviceable at one stage considering their constant re-supply flights to support SANDF troops involved in UN and AU peace missions in Africa. ${ }^{55}$ The SANDF therefore does not currently have the ability to do a battalion-size parachute assault without doing drops in several waves and over many hours or even days (depending on the distances involved).

Unless the SAAF more than doubles its C-130 fleet or acquire other similar transport aircraft, the SANDF will not have the ability to do a rapid parachute assault with a full battalion over long distances. The implication of South Africa's decision to cancel the order for eight A400M transport aircraft with Airbus in late $2009,{ }^{56}$ is that the SAAF will still have insufficient numbers of aircraft to conduct large-scale airborne operations, as well as deploy and support troops for far-off peace missions. The SAAF will not replace its old transport fleet soon due to a limited budget. ${ }^{57}$ The SAAF's limited air transport capability therefore places major constraints on the employment of the SANDF's airborne capability and may inhibit the exploitation of the element of surprise and concentration of force, especially for parachute operations. Parachute operations can, however, not be replaced by airlanded operations since the air-landing of troops and equipment on small airfields can be more time-consuming than parachuting, especially in Africa where inhospitable terrain and limited aviation infrastructure is a common problem. ${ }^{58}$

Another possible constraint on the magnitude of parachute assault operations and particularly deep raids, is the number of troop-carrying helicopters which can evacuate paratroopers during high-risk operations. During Operation Reindeer in 
May 1978 (the SADF airborne assault on Cassinga), for example, the SAAF could only provide 18 Puma helicopters for the extraction, which restricted the size of the assault force to 370 paratroopers and the latter still had to be picked up in two helicopter lifts ${ }^{59}$

Although a small air transport and helicopter fleet places certain limitations on the concentration of an airborne force, a large force can still be prepositioned in more than one wave and over time in a secure environment, if the situation allows it. ${ }^{60}$ Airborne and/or SOF can then infiltrate clandestinely into the area of operations on foot. In the absence of sufficient aircraft to withdraw an airborne force after an operation or phase of an operation, preparations can be made to withdraw such a force with the support of a guerrilla group, a maritime force, or highly mobile land force.

Any SOF and airborne capability is very dependent on air support particularly during high-risk operations. SADF special operations during the SWA/Namibia conflict were no exception. During deliberate attacks with light forces in Angola, two to four Alouette helicopters usually provided much-needed close air support. ${ }^{61}$ With the necessary authorisation, Impala MkIIs were also used for close air support, as well as pinpoint strikes on FAPLA headquarters, antiaircraft and anti-tank positions. The importance of close air support was clearly demonstrated during 32 Battalion's assault on a FAPLA base at Savate in southern Angola in 1980. Initially, 32 Battalion expected to attack a force of no more than battalion strength but found itself fighting a force closer to brigade strength. Without the close air support of Allouette III gunships, 32 Battalion would have been badly mauled and the success would have been much more costly in lives. In theatres such as Afghanistan, where NATO paratroopers currently fight a complex war against a determined Taliban, airborne forces cannot do without gunship support. Armed forces should, however, not become too dependent on close air support.

Since the decommissioning of the Alouette III, the Rooivalk combat support helicopter is the only dedicated helicopter for close air support in the SANDF. It is a critical SOF capability that should support airborne troops and SOF during crisis response and national defence operations. While 16 Squadron (Rooivalk) of the SAAF and 1 Parachute Battalion have done a few exercises together, there is much more scope for developing advanced doctrine, tactics, techniques and procedures (TTPs) for airborne and SOF operations. ${ }^{62}$

According to Alexander, the SANDF does not currently have the logistic capability to conduct independent large-scale airborne operations with 1 Parachute 
Battalion against far-off strategic objectives. ${ }^{63}$ The SANDF's overall airborne capability (including the SAAF and medical component) should be strengthened with the necessary sub-units and support elements in order to be able to deliver at least 1 Parachute Battalion as a battalion group during a parachute assault as well as helicopter-borne operations, to ensure a core and balanced airborne capability. Given South Africa's defence requirements for rapid response operations, as well as its pledges to the SADC Standby Force, the upgrading of the SANDF's airborne capability should be a defence priority. Without a balanced airborne capability, a fully-fledged SOF capability will be difficult to establish.

\section{Conclusions}

Since the end of the Cold War, few countries besides the US have conducted parachute assaults of significant size. The US launched parachute assaults after the terror attacks on the US on 11 September 2001 - first in Afghanistan and then later in Iraq. After the terror attacks, there was a sudden need for SOF in many countries to improve their military security and/or to deploy forces at short notice to remote theatres. The relative affordability and versatility of SOF to conduct a wide variety of specialised military tasks make them an essential capability in modern armed forces. The SA Army in its long-term strategy identified the need for an SOF capability (Contingency Brigade) for crisis response operations, which include parachute, air and sea-landed battalion groups. The aim of the article was to determine the relevance of an airborne capability for South Africa from an SOF perspective.

Although the use of large-scale parachute assaults has declined together with a major decrease in interstate wars, airborne forces remain relevant for current and future operations. The credible threat to employ airborne forces can be used to coerce rogue leaders to accept the terms of the UN or AU and so possibly avoid large-scale multinational interventions. Airborne forces can also be used for quick, mass delivery of forces, as well as smaller clinical SOF operations. Airborne forces will remain relevant to secure airheads and ports of entry, to conduct airborne raids and to conduct counter-insurgency.

The future role of South Africa's parachute forces has been determined largely by the country's defence policy and commitment to multinational responses to security threats, within the framework of the UN and AU security architecture. South Africa's defence policy states that parachute forces fulfil an important role in the landward defence of South Africa, especially in dealing with sudden and unexpected contingencies. This may, for example, include the protection of South 
African citizens in another country. South Africa has pledged a parachute battalion for the SADC Standby Force for rapid response operations, which must be kept on a high readiness state. South Africa, together with other AU member states has committed itself to being able to conduct a wide spectrum of operations under the auspices of the AU, including interventions, peace support operations and humanitarian operations. South African parachute forces should therefore be prepared to be employed in a wide variety of roles on short notice. Ideally, South Africa should develop an SOF capability to expand and enhance the flexibility and robustness of its current rapid response forces. This should include more specialised training in deep semi-independent operations, long-range reconnaissance and patrols, counter-insurgency, infiltration and sabotage. Should the SANDF decide to convert its airborne forces to SOF, this will require significant changes in training and force employment doctrine.

The erosion of South Africa's airborne capability has given it a very limited and predominantly tactical role, providing conventional forces with a small airborne arm for secondary tasks. The SANDF does not have the logistic capability to conduct large-scale independent airborne operations with 1 Parachute Battalion against far-off strategic objectives. The SANDF's overall airborne capability (including the SAAF and medical component) should be strengthened to become a balanced force with the necessary sub-units and support elements to be able to deliver 1 Parachute Battalion as a battalion group during parachute assault as well as helicopter-borne operations. This will, at least, ensure a core and balanced airborne capability. This should be an important stepping stone for the realisation of the envisioned Contingency Brigade, but requires a significant and dedicated increase in the defence budget.

\section{Endnotes}

${ }^{1}$ Horn, B. \& Balasevicius, T. "Introduction”. In Horn, B \& Balasevicius, T (eds), Casting light on the shadows: Canadian perspectives on special operations forces. Toronto: The Dundurn Group, 2007, 14.

${ }^{2}$ Department of Defence, South African Army Headquarters. The future SA Army strategy. Pretoria: Bophirima Print, 2009, 2-28.

${ }^{3}$ Horn, B. "Special operations forces: Uncloaking an enigma". In Horn \& Balasevicius op. cit., p. 30.

${ }^{4}$ Ibid. With reference to Gray, C. Explorations in strategy. London: Greenwood Press, 1996, 149, 190.

${ }^{5}$ US Army. Army special operations forces. Field Manual 3-05/100-25. 2006. 2-1. 
${ }^{6}$ Hammond, JW. "Special operations forces: Relevant, ready and precise". In Horn \& Balasevicius op. cit., pp. 224-226.

${ }^{7}$ Horn op. cit., p. 30.

${ }^{8}$ Ibid.

${ }^{9}$ Ibid., p. 35.

${ }^{10}$ Horn, B. Burn the witch: A case for special operations forces. The Army Training and Doctrine Bulletin 2/3. 1999. 29-30.

${ }^{11}$ Golden, ER. The United States Army in Afghanistan: Operation Enduring Freedom, October 2001 - March 2002. CMH Pub 70-83-1. 2003. 14.

${ }^{12}$ Smith, GR. "Breaking train: Towards relevant Canadian parachute forces". Master's thesis. Canadian Forces College, JCSP 33, 2007, 35.

${ }^{13}$ Wright, RK. \& Greenwood, JT. Airborne forces at war: From parachute test platoon to the $21^{\text {st }}$ century. Annapolis: Naval Institute Press, 2007, 184.

${ }^{14}$ Smith op. cit., pp. 36-37.

15 Ibid.

${ }^{16}$ Tugwell, MAJ. Day of the paratroops. Military Review, March 1977. 48.

${ }^{17}$ Foxton, PD. Powering war: Modern land force logistics. London: Brassey's, 1994, 118-119.

${ }^{18}$ Correspondence with Col. B Horn, Chief of Staff Land Force Doctrine and Training System, Canadian Armed Forces and former Deputy Commander of the Canadian Special Operations Forces Command, 12 January 2010.

${ }^{19}$ Foxton op. cit., pp. 118-119.

${ }^{20}$ Harclerode, P. PARA! Fifty years of the parachute regiment. London: Arms and Armour, 1992, 381.

21 "Kenya police found Mombasa missiles". BBC News, 6 December 2002. <http://news.bbc.co.uk/2/hi/africa/ 2552097.stm> Accessed on 2 May 2011.

${ }^{22}$ Bowden, M. Black Hawk down. London: Corgi Books, 2000, 167.

${ }^{23}$ Heitman, HR. "Airborne operations". Paper presented at a South African Airborne Conference, 1 Parachute Battalion, Tempe, Bloemfontein, 12 June 2007, 1.

${ }^{24}$ Correspondence with Col. B Horn op. cit.

${ }^{25}$ Smith op. cit., p. 76.

${ }^{26}$ Correspondence with Col. B Horn op. cit.

27 Ibid.

${ }^{28}$ Department of Defence. South African Defence Review. As approved by Parliament, April 1998. Pretoria: 1 Military Printing Regiment, 1998, 65.

${ }^{29}$ Department of Foreign Affairs. White Paper on South African participation in international peace missions. As approved by Cabinet on 21 October 1998 and tabled in Parliament on 24 February 1999, 1998, 3.

${ }^{30}$ Protocol Relating to the Establishment of the Peace and Security Council of the African Union, Article 7, July 2002, 9.

${ }^{31}$ SADC Mutual Defence Pact, Article 4, August 2003, 3.

${ }^{32}$ Interview with Capt. (SAN) J Potgieter, former SANDF Advisor to the AU for the establishment of the African Standby Force, 21 May 2008. 
${ }^{33}$ Engelbrecht, L. "SADC Brigade proves mettle". Defenceweb, 28 September 2009. <http://www.defenceweb.co.za/index.php?option=com_content\&task=view \&id=4245\&Itemid=255> Accessed on 2 May 2011 .

${ }^{34}$ Department of Defence. "DOD environmental analysis 2010". Presentation prepared by Col. BR Janssen (Directorate Military Strategy), 29 July 2010.

${ }^{35}$ Cilliers, JK. \& Malan, M. "Progress with the African Standby Force". Institute for Security Studies, Occasional Paper 98, 2005, 3.

${ }^{36}$ Mandrup, T. "South Africa and the SADC Standby Force". Scientia Militaria 37/2. 2009. 15.

${ }^{37}$ Department of Defence, South African Army Headquarters op. cit., pp. 2-28.

${ }^{38}$ Ibid.

${ }^{39}$ Ibid., pp. 2-37.

${ }^{40}$ Ibid., pp. 2-28.

${ }^{41}$ Ibid. 2

${ }^{42}$ Smith op. cit., p. 38.

${ }^{43}$ Telephonic interview with Maj. T Liebenberg, Acting Officer Commanding 1 Parachute Battalion, 25 January 2010.

${ }^{44}$ Ibid.

45 Ibid.

46 Ibid.

${ }^{47}$ Alexander, M. "South African airborne operations". Scientia Militaria 31/1. 2003. $57-61$.

${ }^{48}$ Ibid., pp. 69-70.

${ }^{49}$ Gossmann, AM. "Lost COIN: The erosion of counterinsurgency in the South African Army". In Baker, D. \& Jordaan, E. (eds), South Africa and contemporary counterinsurgency: Roots, practices, prospects. Claremont: UCT Press, 2010, 213.

${ }^{50}$ Interview with Col. MJ van Staden, SSO Operations, 46 South African Brigade Headquarters (former company commander at 1 Parachute Battalion and former operational battalion commander at 32 Battalion), 1 July 2009, Johannesburg.

${ }^{51}$ Alexander op. cit., pp. 66-68.

52 Ibid., p. 69.

${ }^{53}$ Telephonic interview with Maj. T Liebenberg op. cit.

${ }^{54}$ Electronic correspondence with Brig. Gen. (Ret.) M Alexander, Director Project Cleopatra, SANDF Joint Operations Divisional Headquarters, March 2011.

${ }^{55}$ Telephonic interview with Maj. T Liebenberg op. cit.

${ }^{56}$ Engelbrecht, L. "Beyond the A400M". Defenceweb, 13 November 2009. <http://www.defenceweb.co.za/index.php?option=com_content\&task=view \&id=5256\&Itemid=350> Accessed on 2 May 2011 .

${ }^{57}$ Wingrin, D. "No new transports for the SAAF". Defenceweb, 31 January 2011. <http://www.defenceweb.co.za/index.php?view=article\&catid=35\%3AAero space\&id=13333\%3Ano-new-transports-for-thesaaf \&tmpl=component $\&$ print $=1 \&$ layout $=$ default $\&$ page $=\& o p t i o n=c o m \_c o n t$ ent\&Itemid=107> Accessed on 2 May 2011. 
${ }^{58}$ Electronic correspondence with Brig. Gen. (Ret.) M Alexander op. cit.

${ }^{59}$ Breytenbach, JD. "Airborne assault on Cassinga base, 4 May 1978”. Journal for Contemporary History: Grensoorlog: Border War 1966-1989: Special Edition 1/34. 2009. 147.

${ }^{60}$ Electronic correspondence with Maj. Gen. L Rudman, Chief of SA Army Corporate Services, 3 June 2010.

${ }^{61}$ Lord, RS. "SAAF fighter involvement in the Border War, 1965-1988". Journal for Contemporary History 31/3. 2006. 254-256.

62 Telephonic interview with Maj. T Liebenberg op. cit.

${ }^{63}$ Alexander op. cit., p. 81. 